\title{
"Testing of causality relationship between Indian and Australian mutual funds performance: standard vs customized benchmarks"
}

\begin{tabular}{|c|c|}
\hline \multirow{3}{*}{ AUTHORS } & B. R. Manjunath (D) https://orcid.org/0000-0002-5773-748X \\
\hline & J. K. Raju (D https://orcid.org/0000-0002-3130-669X \\
\hline & M. Rehaman (Dttps://orcid.org/0000-0003-1532-7738 \\
\hline ARTICLE INFO & $\begin{array}{l}\text { B. R. Manjunath, J. K. Raju and M. Rehaman (2020). Testing of causality } \\
\text { relationship between Indian and Australian mutual funds performance: standard } \\
\text { vs customized benchmarks. Investment Management and Financial Innovations, } \\
17(3), 231-245 . \text { doi:10.21511/imfi.17(3).2020.18 }\end{array}$ \\
\hline DOI & http://dx.doi.org/10.21511/imfi.17(3).2020.18 \\
\hline RELEASED ON & Thursday, 24 September 2020 \\
\hline RECEIVED ON & Friday, 17 January 2020 \\
\hline \multirow[t]{2}{*}{ ACCEPTED ON } & Tuesday, 15 September 2020 \\
\hline & 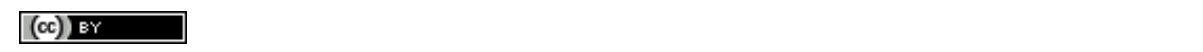 \\
\hline LICENSE & $\begin{array}{l}\text { This work is licensed under a Creative Commons Attribution } 4.0 \text { International } \\
\text { License }\end{array}$ \\
\hline JOURNAL & "Investment Management and Financial Innovations" \\
\hline ISSN PRINT & $1810-4967$ \\
\hline ISSN ONLINE & $1812-9358$ \\
\hline PUBLISHER & LLC "Consulting Publishing Company "Business Perspectives" \\
\hline FOUNDER & LLC "Consulting Publishing Company "Business Perspectives" \\
\hline
\end{tabular}

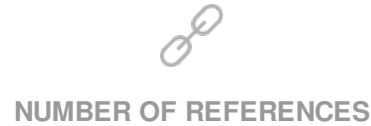

45

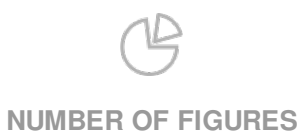

4

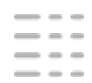

NUMBER OF TABLES

12

(C) The author(s) 2023. This publication is an open access article. 


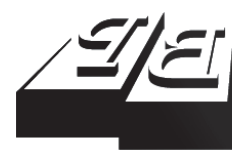

BUSINESS PERSPECTIVES

(2)

LLC "CPC "Business Perspectives" Hryhorii Skovoroda lane, 10, Sumy, 40022, Ukraine www.businessperspectives.org
Received on: $17^{\text {th }}$ of January, 2020 Accepted on: $15^{\text {th }}$ of September, 2020 Published on: $24^{\text {th }}$ of September, 2020

(C) Dr B. R. Manjunath, Dr J. K. Raju, Mr M. Rehaman, 2020

Dr B. R. Manjunath, Associate Professor of Finance and Analytics, Kirloskar Institute of Advanced Management Studies (KIAMS) Harihar, India. (Corresponding author)

Dr J. K. Raju, Professor, Institute of Management Studies, Davangere University, India.

Mr M. Rehaman, Operations Analysis Analyst, IHS Markit, Bangalore, India.

TESTING OF CAUSALITY RELATIONSHIP BETWEEN INDIAN AND AUSTRALIAN MUTUAL FUNDS PERFORMANCE:

\title{
STANDARD VS CUSTOMIZED BENCHMARKS
}

\begin{abstract}
Most Australian domestic investors rely on fund managers, and in India, this is not the same as they are primarily in direct investment rather than indirect. The study attempts to investigate the causal relationship between the returns of the standard indices, namely BSE500 and ASX300, and customized indices, MIMF and MAMF, for both India and Australia. The study uses econometric tools and techniques such as unit root test, vector error correction model, Wald test, Johansen co-integration, and model ef ficacy assumptions on the historical closing NAV of the selected mutual fund schemes for the period from April 2008 to March 2018. The econometric investigation using Johansen's Co-Integration test confirmed the co-integration between BSE500, ASX300 and customized indices. Empirical evidence suggests that the Australian customized MAMF index is not Granger-caused by the Indian customized index MIMF, and therefore the MIMF index value cannot be used to predict the future rate of index MAMF returns, and vice versa.
\end{abstract}

\section{Keywords}

JEL Classification

\section{INTRODUCTION}

Since mutual fund units are managed and operated by experienced fund managers who are experts in their fields, they conduct due diligence and investigation much more effectively and speculate more accurately about market developments. Mutual fund units get more funds from people in general to invest and can get the advantage of economies of scale with a lot of contributed funds. A prerequisite for assessing the performance of Indian and Australian mutual fund schemes for examining the chosen schemes is beating or failing to meet expectations compared to the benchmark; therefore, the study evaluates the performance of open-ended equity schemes (Pandow \& Butt, 2017).

In this way, mutual fund units have profited in diversified portfolios by investing, and this makes them lucrative for investment proposals. A balanced fund is a scheme that transfers its money into equity class and bond class. An aggressive growth stock fund unit invests in high growth-oriented stocks and focuses on capital gain, and there is no pay from profits 'growth stock' identified with an 'aggressive growth stock'. However, it focuses on having higher capital gains (Mamta \& Ojha, 2017).

As most of researchers have evaluated the performance at the levels of scheme, sector, asset classification, and fund management by com- 
paring with the standardized indices, it was decided to assess the dynamics of short- and long-term existing associations between customized Indian Mutual Funds (MIMF) and benchmark BSE500 and customized Australian Mutual Funds (MAMF) and benchmark ASX300, as well as to test the shortand long-term relationship between customized and standard indices. Therefore, a customized index was constructed both for India and Australia, based on price returns of the credit-rated mutual fund schemes. The secondary objective is to investigate the short- and long-run relationship between customized Indian Mutual Funds (MIMF) and customized Australian Mutual Funds (MAMF).

\section{LITERATURE REVIEW}

The performance phenomenon is a useful indicator for any investor when deciding what fund schemes to consider and how to avoid investment. Fund managers have useful and relevant information on forecasted performance evaluation (Brown \& Goetzmann, 1995). Thus, this study tests the relationship pattern by studying the mutual funds' schemes performance in India and Australia, and an effort is made to discuss the issues in detail by using econometric methods. This study is aimed at evaluating open-ended equity schemes and customized benchmark performance for the period from April 2008 to March 2018 using daily scheme returns. In terms of risk implications, this study also presents the performance of mutual fund schemes for systematic risk and total risk using the Treynor, Sharpe and Jensen alpha measures.

Several researchers have analyzed the association between security and mutual fund returns (Rani, \& Hooda, 2017). Some studies explain the dynamic relationship between the stock markets (benchmark) and mutual fund schemes (Watson \& Wickramanayake, 2012). Even though past examinations have researched the association between securities and mutual funds, there is no reasonable proof for the presence of causality and cointegration relationship (Chu, 2010). In past studies, the Granger model was used to determine the long-term relationship between factors, as well as causality techniques - to determine the short-term equilibrium association. The study inspected the elements among fund and securities returns, the causality and Granger ordinary least square (OLS) strategies (1987) were utilized for a period of 2396 day by day closing values from 1994 to 2003. The causality and cointegration tests recommend that the greater part of inflows can anticipate future performance of the market, and the inflow to the stock exchange returns is reasoned (Christos, Nikitas, Theopfano \& Sunil, 2005). The impact of principal factors, namely company, industry, and economy, on the evaluation of mutual fund schemes is justified. The correlation matrix, augmented Dickey-Fuller (ADF) and Granger casualty tests are used to find the connection between variables and their effect on the performance of mutual fund. The research concluded that the real economic variables may not be statistically significant in influencing the mutual fund investment. The analysis of industry shows that the entire mutual fund (managed fund) industry was dominated by only a few players with a huge Asset under Management. The company analysis shows that the Price-to-book ratio and Price-to-earnings ratio have a significant effect on the gains earned by a portfolio followed by its market capitalization and fund/schemes (Rao \& Daita 2011). The association between total equity schemes and excess market returns in the Australian market is found using monthly time series data for the period 1990-2009. A unidirectional causal relationship that runs from stock returns to scheme flows according to the Granger causality test affirms a positive association between scheme and security returns (Watson \& Wickramanayake, 2012).

The risk-return association of equity schemes is investigated. In this study, the equity scheme's performance is explored. An aggregate of 15 schemes offered by a couple of private firms is contemplated over the period from 1999 to 2013. The capital asset pricing model (CAPM) of the risk and return relationship is used to evaluate the performance of mutual fund schemes. The study plans to review and assess the performance of the chosen schemes positioned by CRISIL. All the chosen funds beat the market and showed the prevalent risk of stable performance (Sharma \& Ravikumar, 2013; Rani \& Hooda, 2017). 
The primary objective is to conduct a comparative analysis, measure the risk-return of the chosen fund plans, contrast the equivalent and BSESensex, examine the schemes based on their performance and the market index, as well as to analyze whether they outperform or underperform to meet benchmark expectations. Also, the dimension of enhancement of chosen mutual funds' schemes is examined (Nadia \& Mora, 2018). The study concluded that a few plans may have higher returns and some may have higher risk. This study examines the long- and short-term equilibrium association homogeneity using Vector Error Correction Model (VECM) tests of causality, Wald test, and diagnostic techniques such as heteroskedasticity, histogram, ARCH effect, and Granger causality test.

\section{INDIA AND AUSTRALIA: COMPARATIVE ANALYSIS}

Pragmatic research confirms the integration of Indian and global financial markets (Pokhriyal, L. Singh, \& S. Singh, 2011; Mandaviya, 2014; Mohanasundaram \& Karthikeyan, 2015). Indian stock markets are largely assimilated by global stock markets, more specific to Australia, Germany, the United Kingdom and the United States (Levi, Garag, \& Merlyn, 2016; Paramati, Gupta, \& Roca, 2012). The Indian equity market is associated in the long run with Australian, US, German, and French equity markets but is not interdependent in the short-run with the United Kingdom, France, the United States, and Australia (Chittedi, 2010; Taneja, 2012).

The opportunities for India from Australian investment are seen as significant, and foreign policy frameworks on investment by India will last to open and provide a diversification strategy for typical investors. Australia's investment in Indian markets increased to USD 6.7 billion in 2017, and investment vehicles have an increasing scope that helps mitigate risk and provide steady returns. While Australian financial specialists will choose their own businesses, the expansion of Australian stock investment in India relates to more profound monetary combinations adding to expanded Australian trade commission and exchange. The objective is set as India is turning into the third biggest Australian outbound venture destination in Asia. However, this may be achievable if India's development and economic reforms proceed at stride and if Australian investors move to India (Austrade, 2017).

India's managed fund industry is a potential source of investment for Australia with USD 2.7 trillion in assets under management that attracts India's attention. It inspires ridiculous desires that a huge level of assets can be financed sensibly in India taking into account Greenfield opportunities in the Indian infrastructure sector. A more noteworthy acclimation among Indian and Australian venture experts can link desire breaches to time skylines choices for investment by Australian assets (The Commonwealth of Australia, 2017).

The Australian infra funds are enormous with USD 220 billion of assets under management. Australian experts visiting India will assume a crucial job in improving information about Australia as an investment house. The Government of India and Australian investors will add to a reasonable long-term portfolio investment affiliation by bridging the expectation gap. The International Finance Corporation (IFC) has set up existence in developing markets, for example, India, with a command for engaging worldwide investment. The Australian Government plays a role in promoting the benefits and the need for financial intermediate organizations. The IFC tends to be an avenue to reinforce nearer two-sided investment ties and assist the industry of Australia to explore the stimulating Indian market (Austrade, 2017).

The comparison between India and Australia shows that India has a higher GDP and Australia has a higher GDP per capita. Australia has a low unemployment rate and high current account balance.

According to the CIA World Fact Book 2018 release, the unemployment rate and the inflation rate for India and Australia are 8.5\% and 3.6\% and $5.6 \%$ and $2 \%$, respectively. The GDP real growth rate is $2.2 \%$ in Australia and $6.7 \%$ in India, with 87th rank and 96th rank, respectively (The World Bank, 2018). 
Table 1. Country-wise contribution of the world's largest 500 asset managers

Source: Willis Towers Watson Factbook - World Ranking 2017.

\begin{tabular}{l|c|c}
\hline \multicolumn{1}{c|}{ Country } & $\mathbf{1}$ to $\mathbf{5 0 0}$ & Contribution \\
\hline USA & 195 & $39.00 \%$ \\
\hline UK & 42 & $8.40 \%$ \\
\hline Australia & 22 & $4.40 \%$ \\
\hline India & 8 & $1.60 \%$ \\
\hline Others & 233 & $46.60 \%$ \\
\hline
\end{tabular}

Table 1 shows the contribution of Asset Management Companies (AMC) presence to the top 500 asset managers. The USA is found to have the highest contribution from AMCs to the top 500 results with $39 \%$. The UK stands second with $8.4 \%$, followed by Australia with $4.4 \%$ and India with the $1.6 \%$ contribution to the world's best 500 asset managers. Only eight Indian AMCs have a global presence.

In Table 2, the United States represents the Americas region, and the United Kingdom represents the European region, Australia and India represent the Asia-Pacific region. The United States and Australia dominate their respective region as a pioneer in the managed fund industry (mutual fund industry). Also, there is over tenyear consistency (2008 to 2018) with an average of $88.59 \%$ contribution by the US, $9.56 \%$ by the UK, $38.67 \%$ by Australia, and $3.51 \%$ by India as a presence in the global mutual fund industry.

Therefore, this study examines the relationship between India and the other countries in the context of assets under management by categorizing them according by region, namely Americas, Europe, and Asia-Pacific. As the Americas and Europe mutual fund (managed fund) industry is highly developed, Australia is reasonably considered as a variable to be used to study and compare with India (both countries belong to the Asia-Pacific region).

\section{METHOD}

After the extensive literature review, the essential lagged variables for analyses are considered to test long- and short-run associations using a Vector Error Correction Model. The investigation related to this study is divided into BSE500 and customized Indian Mutual Fund (MIMF), as well as ASX300 and customized Australian Mutual Fund (MAMF) for all study periods.

\subsection{Construction of customized Indian and Australian mutual funds (MIMF and MAMF)}

MIMF is a customized mutual fund representing India. The customized index is constructed based on all the selected mutual fund schemes used for the study; they include Aggressive Hybrid, Conservative Hybrid, Equity-Linked Savings Scheme, Focused funds, Index funds, Large-Cap, Mid-Cap, Multi-Cap, Small Cap, and Thematic Infrastructure and Value funds.

Table 2. Worldwide open-end funds - total net assets

Source: International Investment Funds Association.

\begin{tabular}{|c|c|c|c|c|c|c|c|c|}
\hline Year & World & Americas & US & Europe & UK & Asia Pacific & Australia & India \\
\hline 2008 & $101,977,145$ & $51,252,937$ & $45,928,245$ & $39,394,171$ & $2,921,848$ & $11,017,758$ & $4,305,536$ & 310,123 \\
\hline 2009 & $96,811,448$ & $48,855,689$ & $43,751,953$ & $36,787,160$ & $2,666,209$ & $10,802,582$ & $4,130,405$ & 418,020 \\
\hline 2010 & $108,659,593$ & $54,791,381$ & $48,253,496$ & $40,694,250$ & $3,334,317$ & $12,686,448$ & $5,159,564$ & 474,022 \\
\hline 2011 & $117,132,003$ & $58,970,519$ & $51,280,529$ & $44,073,024$ & $3,870,902$ & $13,557,924$ & $5,857,127$ & 414,196 \\
\hline 2012 & $123,880,742$ & $63,853,372$ & $55,450,463$ & $45,321,746$ & $4,300,418$ & $14,158,196$ & $6,339,904$ & 415,700 \\
\hline 2013 & $138,028,093$ & $71,634,995$ & $62,819,758$ & $50,950,348$ & $5,017,138$ & $14,876,077$ & $6,561,400$ & 430,830 \\
\hline 2014 & $152,534,976$ & $79,038,113$ & $69,774,572$ & $56,589,312$ & $5,828,209$ & $16,316,395$ & $6,811,390$ & 494,578 \\
\hline 2015 & $153,113,354$ & $79,386,350$ & $71,436,263$ & $55,181,755$ & $6,381,197$ & $18,000,425$ & $6,172,757$ & 631,952 \\
\hline 2016 & $160,103,798$ & $82,473,699$ & $73,613,807$ & $56,655,927$ & $6,117,265$ & $20,419,432$ & $6,899,929$ & 763,235 \\
\hline 2017 & $184,609,523$ & $94,037,387$ & $83,531,357$ & $65,842,620$ & $7,047,261$ & $24,072,333$ & $8,211,237$ & $1,106,485$ \\
\hline $2018^{*}$ & $149,530,303$ & $75,563,984$ & $67,599,259$ & $53,374,934$ & $5,782,643$ & $20,077,916$ & $6,298,958$ & 880,636 \\
\hline
\end{tabular}

Note: * represents data available till Q3 2018. 
The schemes were selected from CRISIL and Morningstar. All 173 fund schemes were analyzed, and their daily returns were annualized for quarterly returns for the study period, ten years. Finally, 40 quarterly returns for all ten years are used to compare against the BSE500 and carry out the investigation.

MAMF is a customized mutual fund representing Australia. It is constructed from all the selected mutual fund schemes used for the study, including Blend, Growth, and Value in Large-sized mutual fund schemes, and these schemes were selected from Morningstar Ratings. All 172 fund schemes were analyzed, and their daily returns were annualized for quarterly returns for the study period, ten years. Finally, 40 quarterly returns for all ten years are used to compare against the ASX300 and carry out the investigation.

\subsubsection{Statistical application}

Return on a portfolio is calculated as follows:

$$
R_{p}=\left[\frac{P_{i t}-P_{i t-1}}{P_{i t-1}}\right] \cdot 100,
$$

where $R_{p}$ is the fund return $i$ at time $t, P_{i t}$ is NAV/ fund price $i$ at time $t$.

Daily returns are calculated based on the closing NAV of the Indian and Australian schemes for the study period. Likewise, the returns on the market are considered to be at the average returns for BSE500 and ASX300.

Unit Root Test is used to test the data series stationarity, and after the initial investigation of data unlagged is caught in ordinary least squares method, the lagged models are considered as a necessary investigation in a Vector Error Correction Model. The VECM is intended for cointegrated non-stationary data series (Chu 2011; and Ben-Zion, Choi, \& Hauser, 1996). Many variables considered in financial econometrics are non-stationary (Kirchgassner \& Wolters, 2007). This study emphasizes the testing of unit roots (ADF) to determine non-stationary, at given levels, predetermined variables, and stationarity of first and second differences.

Three problems are identified relating to the non-stationarity and unit roots and data. To be- gin, stationary data has waves that will gradually fade away when non-stationary data shocks have infinite steady behavior. The regression methods estimate non-stationary data, they can display misleading associations with a great explanatory power regardless of variables being non-correlated. Lastly, stationary data assumptions are not substantial for non-stationary data.

There are several ways to deal with a test that data series contains unit roots, and three possible structures under the ADF test:

$$
\begin{aligned}
& \Delta Y_{t}=\delta Y_{t-1}+\sum_{i=1}^{m} \alpha_{i} \Delta Y_{t-1}+\mu_{t} \\
& \Delta Y_{t}=\beta_{1}+\delta Y_{t-1}+\sum_{i=1}^{m} \alpha_{i} \Delta Y_{t-1}+\mu_{t} \\
& \Delta Y_{t}=\beta_{1}+\beta_{2} t+\delta Y_{t-1}+\sum_{i=1}^{m} \alpha_{i} \Delta Y_{t-1}+\mu_{t},
\end{aligned}
$$

where $\Delta$ is a first-difference, $Y$ is a variable checked for stationarity, $t$ is the linear trend (time), and $\boldsymbol{\mu}_{t}$ is a stationarity covariance random error.

The primary structure (equation 1) is correct when it is generated by an arbitrary walk with zero floats and zero mean. The second structure (equation 2) is appropriate when it is created by an arbitrary walk with zero floats and not a zero mean. The third structure (equation 3) is appropriate if the data has not a zero mean and float non-zero, at that point, estimation incorporates both consistent and trend terms. In any case, the unit-roots technique (Perron 1990) contends that the unit root test has low power. At the point when structural breaks are found in the data set, the PP test is presented as dominant as the ADF test (Glynn et al., 2007).

Johansen cointegration tests with the VECM system are used to recognize an association equilibrium between variables in the long run. The cointegration testing of the variables includes the utilization of the likelihood maximum technique (Johansen, 1988). The null hypothesis, $r$ cointegrating relations against $k$ are tested using the Trace test, $k$ is referred to as the number of endogenous factors, for $r=0,1, \ldots, k$ is embraced. The maximum eigenvalue tests are additionally done under the null hypothesis, $r$ cointegrating rela- 
tions against the option of $r+1$. The examination of the model consists of the presumption linear trend in the time series data set, yet no patterns in the cointegrating equations using lagged intervals one or two, as the variables have an increasing pattern (Allen \& MacDonald, 1995). The outcomes for both trace and maximum eigenvalue estimates are considered.

When the level of the data set appeared to be non-stationary, there are first difference stationary associations. The cointegration tests of non-stationary data can be used (Granger, 1986). The two cointegrating equations, namely the trace test and the max eigenvalue test (Johansen \& Juselius, 1990), are as follows:

$$
\begin{aligned}
& \lambda_{\text {trace }}(r)=-T \cdot \sum_{i=r+1}^{n} \ln \left(1-\hat{\lambda}_{1}\right), \\
& \lambda_{\text {max }}(r, r+1)=-T \cdot \ln \left(1-\hat{\lambda}_{r+1}\right),
\end{aligned}
$$

where, $r$ is characterized as the vector cointegrating numbers supporting the null hypothesis, $T$ is a sample unit, and $\hat{\lambda}_{1}$ is the $i$-th correlation. The trace test can also be called as a joint test.

Vector Error Correction Model (VECM): factors in vector $Y_{t}$ are of the integrated order, $I(1)$, cointegrated, and the restrictions on cointegration cannot be applied to the VAR model. Shocks are cointegrated if vector error correction (VEC) exists in the data series (Engle \& Granger, 1987).

Causality test in the case of cointegration existence; homogeneity tests are then conducted on the VECM. Causality means the capacity of one variable comprising helpful data to foresee and consequently impact the estimation of another variable dependent on the ordinary least squares (Diebold, 2007). The confirmation of causality in variable $X_{t}$ has anticipated more prominent exactness by utilizing estimations of the $Y_{t}$ variable in the past, all other factors stay unchanged; this merely confirms that $Y_{t}$ causes $X_{t}$. Subsequently, variables $Y_{t}$ and $X_{t}$ can influence together with distributed lags. The model can be built concerning the time-series data at the level form, $I(1)$, and there are distinct ways to deal with the causality test using the VAR procedure; tests of every variable for their cointegration at $I(1)$ include forecasting the following combination:

$$
\begin{aligned}
& X_{t}=\alpha+\sum_{i=1}^{u} \beta_{i} X_{t-i}+\sum_{j=1}^{v} \gamma_{j} Y_{t-j}+\mu_{t}, \\
& Y_{t}=\alpha+\sum_{i=1}^{w} b_{i} Y_{t-i}+\sum_{j=1}^{v} C_{j} X_{t-j}+\mu_{t},
\end{aligned}
$$

where $\boldsymbol{\mu}_{t}$ is zero-mean, $u, v$, and $w$ are lag lengths.

\section{RESULTS AND DISCUSSION}

Figures 1 and 2 provide visual patterns of both BSE500 and MIMF, and ASX300 and MAMF quarterly returns over the study period, from April 2008 to March 2018. They appear to slant upward when they both tend to be balanced over the study period and BSE500 averages $9.53 \%$ return compared to a higher level of $11.84 \%$ return for customized MIMF and ASX300 averages $2.47 \%$ return compared to a higher level of $6.32 \%$ return for customized MAMF. The graphics indicate the possibility that MIMF and MAMF have been influenced by BSE500 and ASX300, respectively. Therefore, the causality between two data sets cannot be established, there is a necessity for supplementary investigation using the unit root test.

Unit Root Test: Table 3 shows the null hypothesis that BSE500 and MIMF have unit roots and are rejected as the calculated critical value ( $t$-value) for MIMF is less than $5 \%$ at the second difference $I(2)$ at the significance level. The test reveals that the MIMF variable is non-stationary and becomes stationary after the second difference. The outcome of the regression from the VECM model is spurious. To withdraw this, a regression equation is performed with stationary variables after differencing (Granger \& Newbold, 1974).

For MIMF, $t$-value -6.275272 is lower than the calculated Augmented Dickey-Fuller (ADF) test critical t-value (-2.95113) at a 5\% significance level. Likewise, for BSE500, at the level, $\mathrm{t}$-value -5.82826 is less than the calculated ADF test calculated critical value $(-2.93899)$ at a 0.05 significance level. Thus, BSE500 and MIMF data sets have no unit root problems and are good to continue with the co-integration test. 

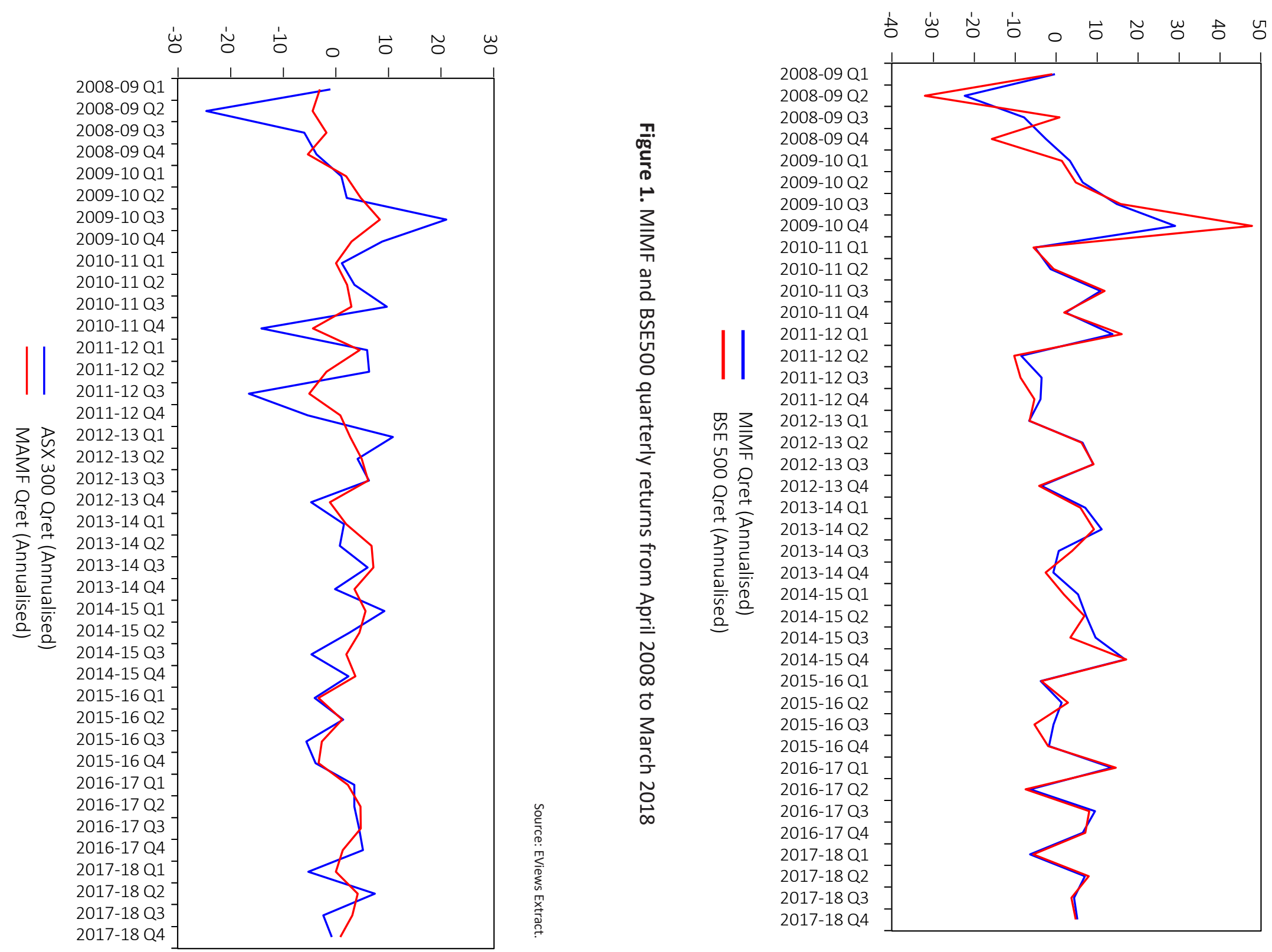
Table 3. ADF test - MIMF and BSE500

Source: EViews software output.

\begin{tabular}{|c|c|c|c|c|c|c|c|c|}
\hline \multirow{2}{*}{ Particulars } & \multicolumn{4}{|c|}{ MIMF } & \multicolumn{4}{|c|}{ BSE500 } \\
\hline & T-statistic & \multicolumn{2}{|c|}{ Critical value } & P-value & T-statistic & & al value & P-value \\
\hline \multirow{3}{*}{ At level } & \multirow{3}{*}{-5.41779} & $1 \%$ & -3.61045 & \multirow{3}{*}{0.0001} & \multirow{3}{*}{-5.82826} & $1 \%$ & -3.61045 & \multirow{3}{*}{0} \\
\hline & & $5 \%$ & -2.93899 & & & $5 \%$ & -2.93899 & \\
\hline & & $10 \%$ & -2.60793 & & & $10 \%$ & -2.60793 & \\
\hline \multirow{3}{*}{ At first difference } & \multirow{3}{*}{-4.87989} & $1 \%$ & -3.6329 & \multirow{3}{*}{0.0003} & \multirow{3}{*}{ NA } & $1 \%$ & NA & \multirow{3}{*}{ NA } \\
\hline & & $5 \%$ & -2.9484 & & & $5 \%$ & NA & \\
\hline & & $10 \%$ & -2.61287 & & & $10 \%$ & NA & \\
\hline \multirow{3}{*}{$\begin{array}{l}\text { At second } \\
\text { difference }\end{array}$} & \multirow{3}{*}{-6.27527} & $1 \%$ & -3.63941 & \multirow{3}{*}{0} & \multirow{3}{*}{ NA } & $1 \%$ & NA & \multirow{3}{*}{ NA } \\
\hline & & $5 \%$ & -2.95113 & & & $5 \%$ & NA & \\
\hline & & $10 \%$ & -2.6143 & & & $10 \%$ & NA & \\
\hline
\end{tabular}

Table 4. ADF test - ASX300 and MAMF

Source: EViews software output.

\begin{tabular}{|c|c|c|c|c|c|c|c|c|}
\hline \multirow{2}{*}{ Particulars } & \multicolumn{4}{|c|}{ ASX300 } & \multicolumn{4}{|c|}{ MAMF } \\
\hline & T-statistic & & I value & P-value & T-statistic & Cri & value & P-value \\
\hline \multirow{3}{*}{ At level } & \multirow{3}{*}{-5.6339} & $1 \%$ & -3.6105 & \multirow{3}{*}{0.0000} & \multirow{3}{*}{-4.3235} & $1 \%$ & -3.6105 & \multirow{3}{*}{0.0015} \\
\hline & & $5 \%$ & -2.9389 & & & $5 \%$ & -2.9389 & \\
\hline & & $10 \%$ & -2.6079 & & & $10 \%$ & -2.6079 & \\
\hline \multirow{3}{*}{ At first difference } & \multirow{3}{*}{ NIL } & $1 \%$ & NIL & \multirow{3}{*}{ NA } & \multirow{3}{*}{-6.2384} & $1 \%$ & -3.6210 & \multirow{3}{*}{0.0000} \\
\hline & & $5 \%$ & NIL & & & $5 \%$ & -2.9434 & \\
\hline & & $10 \%$ & NIL & & & $10 \%$ & -2.6103 & \\
\hline
\end{tabular}

Table 4 confirms for MAMF that $t$-value -4.3235 is lesser than the ADF test critical calculated value $(-2.9389)$ at a $5 \%$ significance level. Similarly, for ASX300, the calculated t-value (-5.6339) is less than the calculated ADF test critical calculated value $(-2.9389)$ at a $5 \%$ significance level. Thus, it has been decided that ASX300 and MAMF have no unit root problem.

Test of Johansen's Co-Integration: Table 5 shows the statistic for the Max. Eigen calculated value (16.59258) greater than the calculated critical value (15.495) specifying that the variables in the long-run associations are bound together. The presence of co-integration between the variables is found for the null hypothesis. In the same way, Max. Eigen test also shows co-integration between the two variables and the presence in the long run, as the Max. Eigen calculated t-statistic value (11.04530) is less than the calculated critical $t$-value (14.26460) at the level of significance $5 \%$. The results indicate the null hypothesis, co-integration between MIMF and BSE500 is not found and rejected at a 0.05 level of significance, since Max. Eigen test and Trace test indicate at most one co-integration equation at the $5 \%$ level. Hence,

Table 5. Johansen co-integration test outcome - MIMF and BSE500

Source: EViews software output

\begin{tabular}{l|c|c|c|c}
\hline \multicolumn{1}{c}{ Cointegration test } & Level & Eigen values & $\begin{array}{c}\text { Trace/Max-Eigen } \\
\text { statistic }\end{array}$ & Critical values (5\%) \\
\hline \multirow{2}{*}{ Trace test } & $\mathrm{H}_{0} \mathrm{r}=0$ (none) & P-value & 15.49471 \\
& $\mathrm{H}_{1} \mathrm{r}=1$ (At most 1) & 0.146572 & 16.59258 & 0.0341 \\
& $\mathrm{H}_{0} \mathrm{r}=0$ (none) & 0.270634 & 5.547279 & 0.0185 \\
Max. Eigen & $\mathrm{H}_{1} \mathrm{r}=1$ (At most 1) & 0.146572 & 11.04530 & 5.841466 \\
\end{tabular}

Note: Trace indicates two cointegrating eqn(s), and Max Eigen indicates no cointegration (5\%), * Hypothesis rejected at the $5 \%$ significance level. 
Table 6. Johansen co-integration test outcome - MAMF and ASX300

Source: EViews software output.

\begin{tabular}{|c|c|c|c|c|c|}
\hline Co-integration test & Level & Eigen values & $\begin{array}{c}\text { Trace/Max. Eigen } \\
\text { statistics }\end{array}$ & Critical values $(5 \%)$ & P-value \\
\hline \multirow{2}{*}{ Trace test } & $\mathrm{H}_{0} \mathrm{r}=\mathrm{O}$ (none) ${ }^{*}$ & 0.38569 & 20.6256 & 15.4947 & 0.0077 \\
\hline & $\mathrm{H}_{1} \mathrm{r}=1$ (At most 1$)$ & 0.09702 & 3.5720 & 3.8417 & 0.0588 \\
\hline \multirow{2}{*}{ Max. Eigen } & $\mathrm{H}_{0} \mathrm{r}=\mathrm{O}$ (none) ${ }^{*}$ & 0.38569 & 17.0537 & 14.2646 & 0.0176 \\
\hline & $\mathrm{H}_{1} \mathrm{r}=1$ (At most 1$)$ & 0.09702 & 3.5720 & 3.8415 & 0.0588 \\
\hline
\end{tabular}

Note: Trace and Max-Eigen indicate one co-integrating equation; * - hypothesis is rejected at a $5 \%$ significance level.

the alternative hypothesis is accepted, and there is cointegration between MIMF and BSE500.

Similarly, no co-integration is found between MAMF and ASX300 data sets; it is rejected at a 0.05 significance level as the trace and Max. Eigen tests show at most one co-integration equation at a 5\% significance level (see Table 6). Therefore, it is proposed that a cointegration equation between MAMF and ASX300 is accepted.

Table 7 shows that subsequent analysis involves fitting the data series into a VECM and the outcomes are based on a normalized eigenvector; they show a positive long-run association between BSE500 and MIMF, and the calculated co-integrating coefficient for the BSE500 growth is as follows:

$$
\begin{aligned}
& M I M F=0.524254 B S E 500- \\
& -1.99287[-5.76031] .
\end{aligned}
$$

The t-statistic co-integrating coefficient for BSE500 is shown in the parentheses (Table 7). The BSE500 coefficient is negative, which means the existence of positive long-run association between MIMF returns and BSE500 returns. Also, an increase in BSE500 can be associated with an increase in the MIMF returns in India.

Table 7. Co-integrating vector of MIMF and BSE500

Source: EViews software output.

\begin{tabular}{c:c:c}
\hline \multicolumn{3}{c}{ Co-integrating equation } \\
\hline MIMF & BSE500 & Constant \\
\hline & -0.524254 & \\
1 & $(-0.09101)$ & -1.99287 \\
& {$[-5.76031]$} & \\
\hline
\end{tabular}

Note: Standard error is in ( ), t-statistics is in [ ].
Table 8 shows that the negative error correction coefficient $(-2.651364)$ is significant at a $5 \%$ significance level, and the t-statistic value is lower $(-2.36258)$ compared to the critical calculated value (1.96) at $5 \%$ level of significance. Therefore, this confirms the long-run association between BSE500 and MIMF. Therefore, it can be said that the value of succeeding year MIMF returns is inclined by the base (current) year BSE500 at a 95\% confidence level. The VECM outcome shows that MIMF has a positive significant long-run impact on the economic growth and development of the Indian economy, benchmark BSE500.

\subsubsection{Dependent variable: MIMF; Independent variable: BSE500}

\section{System equation}

$$
D(M I M F)=C(1) \times
$$

$\times(\operatorname{MIMF}(-1)-0.52425366658) \times$

$\times($ BSE 500) $(-1)(-1.99287426315)+$

$+C(2) \cdot(D(\operatorname{MIMF}(-1))+C(3)) \times$

$\times(D(\operatorname{MIMF}(-2))+C(4)) \times$

$\times(D(\operatorname{MIMF}(-3))+C(5)) \times$

$\times(D(M I M F(-4))+C(6)) \times$

$\times(D(B S E 500(-1))+C(7)) \times$

$\times(D(B S E 500(-2))+C(8)) \times$

$\times(D(B S E 500(-3))+C(9)) \times$

$\times(D(B S E 500(-4))+C(10))$. 
Table 8. Long-run causality variable (least squares) of MIMF and BSE500

\begin{tabular}{|c|c|c|c|c|}
\hline \multirow{2}{*}{ Coefficient } & \multirow[b]{2}{*}{ Coefficient Value } & & \multicolumn{2}{|c|}{ Source: Output extract from EViews software. } \\
\hline & & Std. error & t-statistic & Prob. \\
\hline$C(1)$ & -2.651364 & 1.122231 & -2.362583 & 0.0262 \\
\hline$C(2)$ & 1.960373 & 0.922896 & 2.124154 & 0.0437 \\
\hline$C(3)$ & 1.718254 & 0.737282 & 2.330524 & 0.0281 \\
\hline$C(4)$ & 1.636550 & 0.593672 & 2.756657 & 0.0107 \\
\hline$C(5)$ & 1.078197 & 0.450670 & 2.392430 & 0.0246 \\
\hline$C(6)$ & -1.541256 & 0.539152 & -2.858666 & 0.0085 \\
\hline$C(7)$ & -1.350486 & 0.482506 & -2.798900 & 0.0097 \\
\hline$C(8)$ & -1.159884 & 0.423449 & -2.739135 & 0.0112 \\
\hline$C(9)$ & -0.907368 & 0.310933 & -2.918208 & 0.0073 \\
\hline$C(10)$ & 0.202426 & 1.406407 & 0.143931 & 0.8867 \\
\hline R-squared & 0.644686 & & & \\
\hline
\end{tabular}

C (1) is statistically significant as the p-value is lower than $5 \%$ and has a negative coefficient. This indicates a long-term causality resulting from MIMF and BSE500. Therefore, the error correction term variable is significant. Thus, a long-run causality runs from the independent variable to the dependent variable. R-squared (0.644686) statistic estimates the efficiency of the regression analysis in forecasting the values of the dependent variable (MIMF) in the sample. R-squared may be represented as the fraction of the dependent variable (MIMF) variance described by the independent variable (BSE500). Similarly, VECM shows a positive long-run relationship between ASX300 and MAMF. The calculated co-integrating coefficient for the ASX300 growth is as follows:

$$
\begin{aligned}
& M A M F=12.3979- \\
& -8.3606 A S X 300[-4.1912] .
\end{aligned}
$$

The co-integrating coefficient $\mathrm{t}$-statistic value of ASX300 is given in the parentheses as a negative coefficient for ASX300, indicating a positive long-run association between MAMF returns and ASX300 returns. Also, an increase in ASX300 can be associated with an increase in the MAMF returns in Australia. Table 9 shows that the coefficient error correction term $(0.07322)$ is positive and p-value (0.0075) is less than $5 \%$; it is said that the variable is statistically significant at a $5 \%$ significance level, since it is represented by the higher t-statistic calculated value (2.9085 and 3.9536) compared to the critical value (1.96) at a $5 \%$ significance level. Therefore, this confirms the relationship between ASX300 and MAMF as a long- term equilibrium and the value of succeeding year MAMF returns are essentially affected by the base (current) year ASX300 at a 95\% confidence level. VECM confirms that MAMF has a significant positive long-run impact on the economic growth in Australia, ASX300.

\subsubsection{Dependent variable: MAMF Independent variable: ASX300}

\section{System equation}

$$
\begin{aligned}
& D(M A M F)=C(1) \times \\
& \times((M A M F(-1)-8.36056847235) \times \\
& \times(A S X 300(-1)+2.3979182847)+C(2)) \times \\
& \times(D(M A M F(1))+C(3)) \times \\
& \times(D(M A M F(-2))+C(4)) \times \\
& \times(D(M A M F(-3))+C(5)) \times \\
& \times(D(M A M F(-4))+C(6)) \times \\
& \times(D(A S X 300(-1))+C(7)) \times \\
& \times(D(A S X 300(-2))+C(8)) \times \\
& \times(D(A S X 300(-3))+C(9)) \times \\
& \times(D(A S X 300(-4))+C(10))
\end{aligned}
$$

C (1) is highly significant as the probability is less than $5 \%$ significance level and causality in the long run is running through MAMF and ASX300. However, the coefficient is positive and the p-value is significant as it is less than 0.05; a long-run 
Table 9. Long-run causality variable (least squares) of MAMF and ASX300

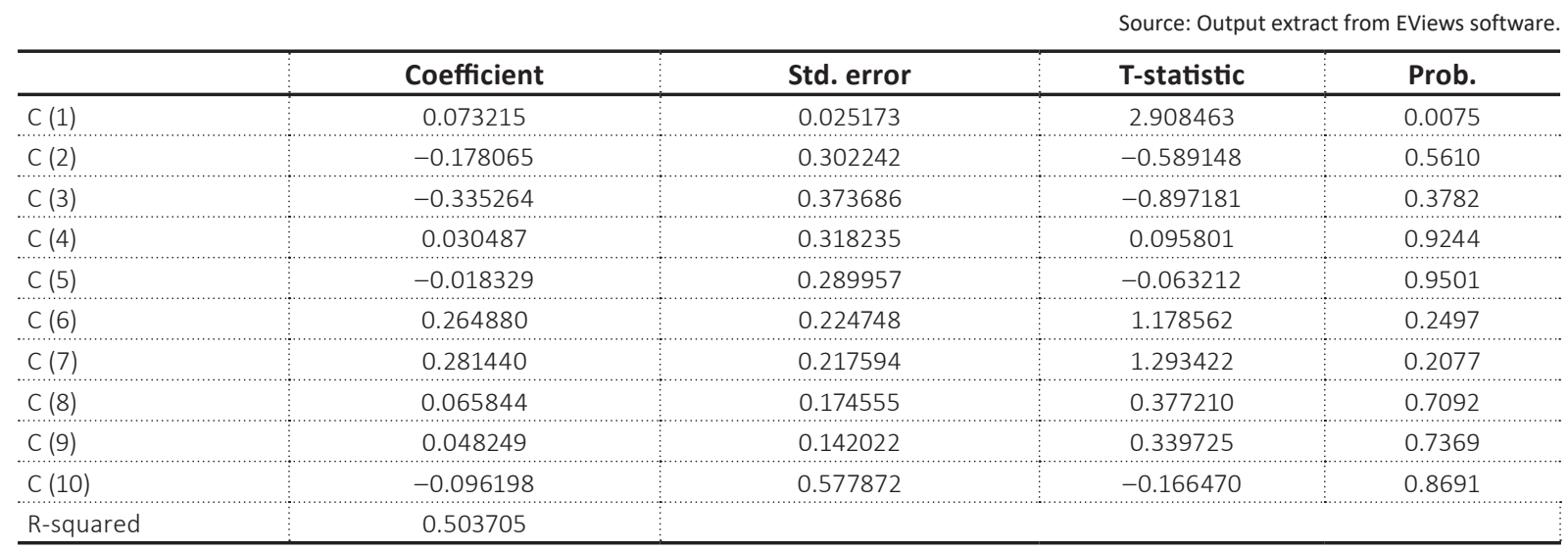

causality can be determined. R-squared (0.5037) statistic estimates the efficiency of the regression in forecasting the value of the dependent variable (MAMF). R-squared may be understood as the fraction of the dependent variable (MAMF) variance described by the independent variable (ASX300).

Wald test: Null hypotheses for the short run: $c(6)$ $=c(7)=c(8)=c(9)=0$.

Table 10 confirms that $\mathrm{p}$-value is less than $5 \%$; this rejects the null hypothesis, resulting in a short-run causality coming through the independent variable (BSE500) to the dependent variable (MIMF) and the independent variable (ASX300) to the dependent variable (MAMF).

Wald statistics is used to check a combination of data series, MIMF and BSE500, and MAMF and ASX300.

- Long-run causality from BSE500 to MIMF and ASX300 to MAMF.

- Short-run causality from BSE500 to MIMF and ASX300 to MAMF.
Table 10. Wald test results for MIMF and BSE500 and MAMF and ASX300

Source: Output extract from EViews software.

\begin{tabular}{l|c:c:c:c}
\hline \multicolumn{1}{c|}{ Case } & $\begin{array}{c}\text { Test } \\
\text { statistic }\end{array}$ & Value & df & Prob. \\
\hline MIMF and & F-stat & 3.935965 & $(4,25)$ & 0.0130 \\
BSE500 & Chi-square & 15.74386 & 4 & 0.0034 \\
MAMF and & F-stat & 0.758529 & $(4,25)$ & 0.5620 \\
ASX300 & Chi-square & 3.034114 & 4 & 0.5521 \\
\hline
\end{tabular}

Histogram: Figures 3 and 4 confirm that the null hypothesis is accepted as the Jarque-Bera and probability are more than $5 \%$. Therefore, the residuals are normally distributed and the constructed model is desirable for normality test on MIMF and BSE500 (JarqueBera $=0.72$ ); MAMF and ASX300 (Jarque- Bera $=1.51)$.

Heteroskedasticity test and serial test: Table 11 shows the observed R-squared and probability. The Chi-square probability is greater than 0.05 , indicating that the null hypothesis is accepted. There is no Arch effect and serial correlation. It is a good-fit sign and it satisfies the model specification assumption for the cases; Heteroskedasticity Test (ARCH) results for MIMF and BSE500; MAMF and ASX300 and Breusch Godfrey Serial

Table 11. Heteroskedasticity and serial correlation test

Source: Output extract from EViews software.

\begin{tabular}{|c|c|c|c|c|c|c|c|}
\hline \multirow{3}{*}{$\begin{array}{l}\text { MIMF and } \\
\text { BSE500 }\end{array}$} & \multirow[b]{2}{*}{ F-stat } & \multicolumn{3}{|c|}{ Heteroskedasticity } & \multicolumn{3}{|c|}{ Serial correlation } \\
\hline & & 0.2802 & Prob. $F(4,26)$ & 0.888 & 1.01212 & Prob. F $(4,21)$ & 0.424 \\
\hline & Obs. * R-squared & 1.28113 & Prob. Chi-square (4) & 0.865 & 5.65691 & Prob. Chi-square (4) & 0.226 \\
\hline \multirow{2}{*}{$\begin{array}{l}\text { MAMF and } \\
\text { ASX300 }\end{array}$} & F-stat & 1.6635 & Prob. $F(4,26)$ & 0.189 & 2.5134 & Prob. F $(4,21)$ & 0.072 \\
\hline & Obs. * R-squared & 6.31696 & Prob. Chi-square (4) & 0.177 & 11.3312 & Prob. Chi-square (4) & 0.023 \\
\hline
\end{tabular}


Source: EViews software analysis results.

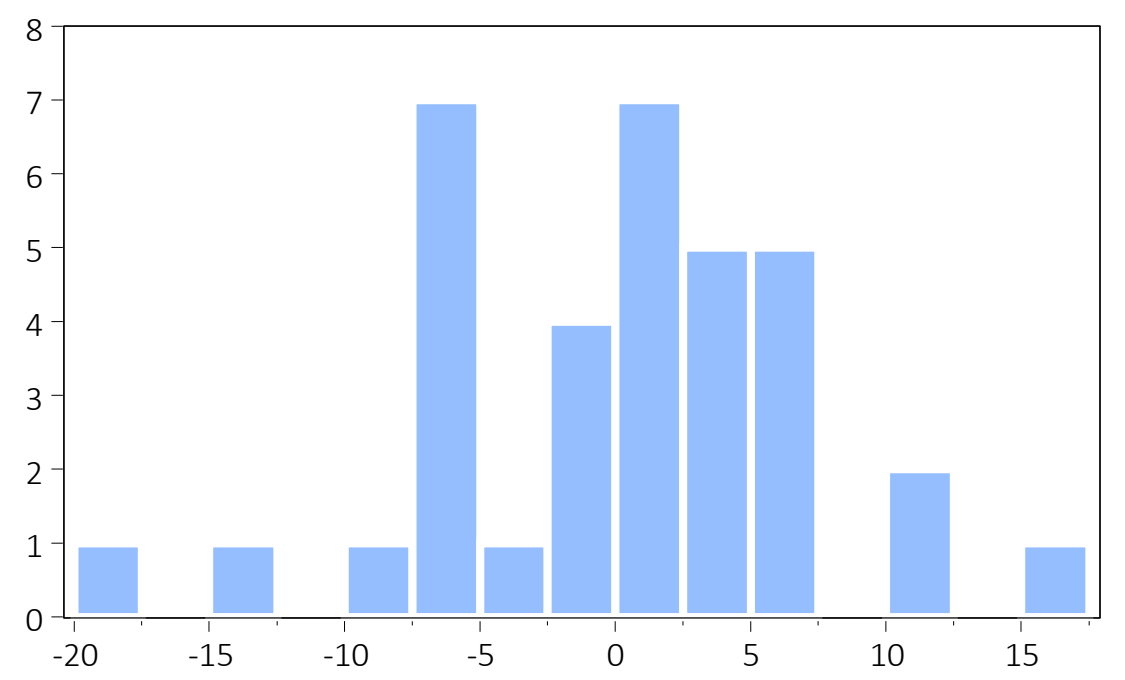

$\begin{array}{ll}\text { Series: } & \text { Residuals } \\ \text { Sample } & 640 \\ \text { Observations } & 35 \\ & \\ \text { Mean } & 6.60 \mathrm{e}-16 \\ \text { Median } & 0.790599 \\ \text { Maximum } & 15.34799 \\ \text { Minimum } & -18.24443 \\ \text { Std. Dev. } & 7.020229 \\ \text { Skewness } & -0.308036 \\ \text { Kurtosis } & 3.257345 \\ & \\ \text { Jarque-Bera } & 0.650083 \\ \text { Probability } & 0.722497\end{array}$

Figure 3. Normality test for MIMF and BSE500

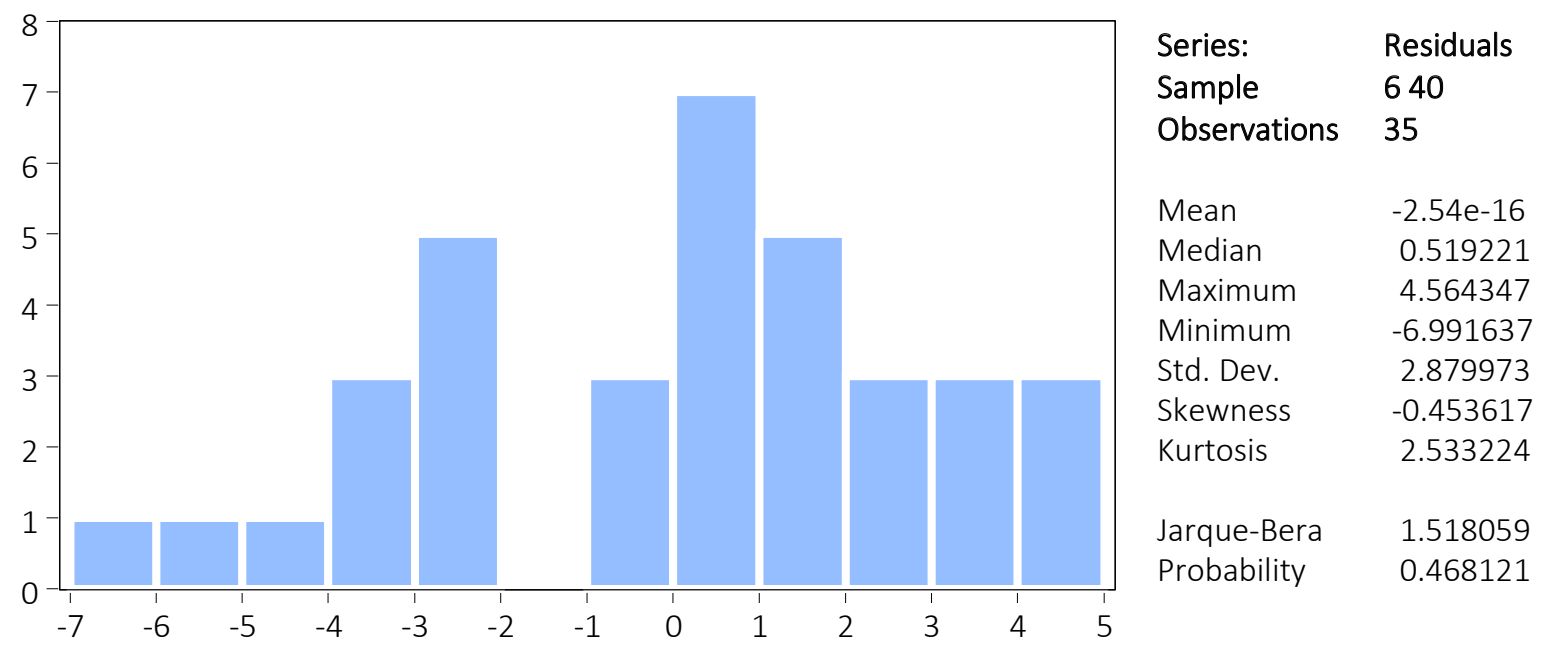

Figure 4. Normality test for MAMF and ASX300

Correlation Test for MIMF and BSE500; BSE500 and ASX300.

Granger causality test results are shown in Table 12. There is no causality between MIMF quarterly returns and BSE500 quarterly returns, and vice versa. MIMF quarterly returns do not Granger-cause BSE500 quarterly returns and BSE500 quarterly returns do not Granger-cause MIMF quarterly returns; Indian perspective appears to be bi-directional.

BSE500, in fact, does not necessarily lead to increases or decreases in MIMF return levels.
Correspondingly, BSE500 does not Grangercause MIMF, and the MIMF value cannot be employed to forecast the level of BSE500 in future; this is in line with previous similar studies (Gordon, 2017). Similarly, it indicates that, to a significant extent, ASX300 quarterly returns do not essentially have to lead or attract to increasing or decreasing levels of MAMF quarterly returns. Similarly, ASX300 quarterly returns are Granger-caused by MAMF quarterly returns, and, therefore, the value of MAMF quarterly returns cannot be used to forecast the future level of ASX300 quarterly returns. 
Table 12. Granger causality test

Source: Author's computation using EViews software.

\begin{tabular}{|c|c|c|c|c|}
\hline Null hypothesis & Obs. & F-stat & Prob. & Decision \\
\hline BSE500 does not Granger cause MIMF returns & 36 & 0.506 & 0.732 & Accepted \\
\hline MIMF does not Granger cause BSE500 returns & 36 & 0.481 & 0.749 & Accepted \\
\hline ASX300 does not Granger cause MAMF returns & 36 & 1.718 & 0.175 & Accepted \\
\hline MAMF does not Granger cause ASX300 returns & 36 & 1.921 & 0.136 & Accepted \\
\hline
\end{tabular}

\section{CONCLUSION}

Thus, the investigation shows that the returns of the Indian customized fund (MIMF) and BSE500 and Australian customized fund (MAMF) and ASX300 of mutual fund schemes are cointegrated. The presence of cointegrating equations between variables that provide rational expectations theory combined with past research and demonstrate long-run returns will be highly correlated. In the short run, Wald's test aims to identify the causal relationship of variables and the presence of a short-run proof of causal relationships between Indian customized funds (MIMF) and BSE500 and Australian customized funds (MAMF) and ASX300. The results show that any changes in the scheme's NAV (prices) cannot be used to foresee the direction of the Indian customized fund (MIMF) and BSE500 and the Australian customized fund (MAMF) and ASX300, respectively.

Thus, investing in specific mutual funds offers an alluring alternative for investors who need to build their portfolios in order to provide a similar pattern of the Indian and Australian benchmark indices. The proof of cointegration and causality suggests the likelihood of arbitrage benefitting, as investors are more likely to gain knowledge into the mutual fund performance, not just only depending on the movement of a standard index like BSE500 and ASX300. Fund managers achieve incredible success according to a positive alpha, which means that an investor should rely on numerous tools and techniques available to evaluate mutual fund schemes using performance indicators.

\section{FUTURE RESEARCH}

There is a scope for investment banks to make their customized indices publicly available for investors so that they can make the benchmark analysis rather than relying on the national standard index as a whole to compare against a fund or portfolio created by fund managers of asset management companies.

\section{AUTHOR CONTRIBUTIONS}

Conceptualization: B. R. Manjunath, J. K. Raju.

Data curation: B. R. Manjunath, M. Rehaman.

Formal analysis: B. R. Manjunath.

Investigation: B. R. Manjunath.

Methodology: B. R. Manjunath.

Project administration: M. Rehaman.

Software: B. R. Manjunath.

Supervision: J. K. Raju.

Validation: J. K. Raju.

Writing - original draft: B. R. Manjunath, M. Rehaman.

Writing - review \& editing: B. R. Manjunath, J. K. Raju, M. Rehaman. 


\section{REFERENCES}

1. Alexakis, C., Niarchos, N., Patra, T., \& Poshakwale, S. (2005). The dynamics between stock returns and mutual fund flows Empirical evidence from the Greek market. International Review of Financial Analysis 14(5), 559-569. https://doi. org/10.1016/j.irfa.2004.10.019

2. Allen, D. E., \& Macdonald, G. (1995). The long-run gains from international equity diversification: Australian evidence from cointegration tests. Applied Financial Economics, 5(1), 33-42. https://doi.org/10.1080/758527669

3. Aro-Gordon, S. (2017). Econometric analysis of exchange rate and export performance in a developing economy. Asian Economic and Financial Review, 7(4), 334-348. https:// doi.org/10.18488/journal. aefr/2017.7.4/102.4.334.348

4. Australia Trade and Investment Commission (Austrade). (2017). Australia's Managed Funds 2017 Update (Trade and Investment Note). Canberra AU: The Commonwealth of Australia. Retrieved from https://www. austrade.gov.au/ArticleDocuments/5720/2017_Australias-Managed-Fund-Update.pdf

5. Australian Government. (2018). All India Economic Strategy 2035 (Chapter 2. The Investment Story). Retrieved from https://www.dfat. gov.au/geo/india/ies/chapter-2.html

6. Benson, K. L., \& Faff, R. W. (2006). Conditional performance evaluation and the relevance of money flow for Australian international equity funds. PacificBasin Finance Journal, 14(3), 231-249. https://doi.org/10.1016/j. pacfin.2005.10.002

7. Ben-Zion, U., Choi, J. J., \& Hauser, S. (1996). The price linkages between country funds and national stock markets: Evidence from cointegration and causality tests of Germany, Japan, and UK funds. Journal of Business Finance \& Accounting, 23(7), 1005-1017. https://doi. org/10.1111/j.1468-5957.1996. tb01037.x
8. Bollerslev, T. (1986). Generalized autoregressive conditional heteroskedasticity. Journal of Econometrics, 31(3), 307-327. https://doi.org/10.1016/03044076(86)90063-1

9. Boudreaux, D. O., Rao, U. S. P., Ward, D., \& Ward, S. (2007). Empirical Analysis of international mutual fund performance. International Business \& Economics Research Journal, 6(5), 19-22. https://doi.org/10.19030/iber. v6i5.3367

10. Brown, S. J., \& Goetzmann, W. N. (1995). Performance Persistence. The Journal of Finance, 50(2). https://doi. org/10.1111/j.1540-6261.1995. tb04800.x

11. Chittedi, K. R. (2010). Integration of international stock markets: With special reference to India. GITAM Journal of Management, 9(3), 1-16. https://doi.org/10.2139/ ssrn. 1667862

12. Chu, P. K. K. (2010). The price linkages between the equity fund price levels and the stock markets: Evidence from the cointegration approach and causality analysis of the Hong Kong Mandatory Provident Fund (MPF). International Review of Financial Analysis, 19(4), 281-288. https://doi. org/10.1016/j.irfa.2010.08.001

13. CIA Factbook. (2020a). Australia Economy 2020. Retrieved from https://theodora.com/wfbcurrent/ australia/australia_economy.html

14. CIA Factbook. (2020b). India Economy 2020. Retrieved from https://theodora.com/wfbcurrent/ india/india_economy.html

15. Connor, G., \& Korajczyk, R. A. (1988). Risk and return in an equilibrium APT: Application of a new test methodology. Journal of Financial Economics, 21(2), 255-289. https://doi.org/10.1016/0304405X(88)90062-1

16. Debasish, S. S. (2009). Investigating the performance of equity-based mutual fund schemes in Indian scenario. KCA Journal of Business Management, 2(2), 1-15. https://doi. org/10.4314/kjbm.v2i2.52160
17. Diebold, F. X. (2007).

Macroeconomic Volatility and Stock

Market Volatility, Worldwide (NBER Working Paper 14269). https://doi. org/10.3386/w14269

18. Engle, R., \& Granger, C. (1987). CoIntegration and Error Correction: Representation, Estimation, and Testing. Econometrica, 55(2), 251-276. https://doi. org/10.2307/1913236

19. Getmansky, M., Lo, A. W., \& Makarov, I. (2004). An econometric model of serial correlation and illiquidity in hedge fund returns. Journal of Financial Economics, 74(3), 529-609. https://doi. org/10.1016/j.jfineco.2004.04.001

20. Glynn, J., Perera, N., \& Verma, R. (2007). Unit Root Tests and Structural Breaks: A Survey with Applications. Journal of Quantitative Methods for Economics and Business Administration, 34(1), 63-79. Retrieved from https:// www.researchgate.net/publication/30387415_Unit_Root_Tests_ and_Structural_Breaks_A_Survey_with_Applications

21. Granger, C. W. J., \& Newbold, P. (1974). Spurious regressions in econometrics. Journal of Econometrics, 2(2), 111-120. https://doi.org/10.1016/03044076(74)90034-7

22. International Investment Funds Association (IIFA). (2020). Industry Statistics. Retrieved from https:// www.iifa.ca/industry_statistics/ index.html

23. Ippolito, R. A. (1989). The efficiency with costly information: A study of mutual fund performance, 1965-1984. Quarterly Journal of Economics, 104(1), 1-23. https://doi. org/10.2307/2937832

24. Johansen, S. (1988). Statistical analysis of cointegration vectors. Journal of Economic Dynamics and Control, 12(2-3), 231-254. https://doi.org/10.1016/01651889(88)90041-3

25. Johansen, S., \& Juselius, K. (1990). Maximum Likelihood Estimation and Inference on Cointegration with Applications to Demand 
for Money. Oxford Bulletin of Economics and Statistics, 52(2), 169210. Retrieved from https://EconPapers.repec.org/RePEc:bla:obuest:v:5 2:y:1990:i:2:p:169-210

26. Kirchgässner, G., \& Wolters, J. (2007). Introduction to Modern Time Series Analysis. Retrieved from https://www.springer.com/gp/ book/9783540732914

27. Levi, S., Garag, A. K., \& Merlyn, S. (2016). An empirical study on the performance of emerging and developed stock markets concerning the Indian stock market. International Educational Scientific Research Journal, 2(12), 92-96. Retrieved from https://iesrj.com/ archive-sub?detail=AN_EMPIRICAL_STUDY_ON_PER

28. Low, S.-W. \& Ghazali, N. A. (2007). The price linkages between Malaysian unit trust funds and the stock market: Short run and long run interrelationships. Managerial Finance, 33(2), 89-101. https://doi. org/10.1108/03074350710715827

29. Mamta, \& Ojha, S. C. (2017). Performance Evaluation of Mutual Funds: A Study of Selected Equity Diversified Mutual Funds in India. International Journal of Research in Business Management, 5(11), 85-92. Retrieved from http://oaji.net/ articles/2017/490-1513334779.pdf

30. Mandaviya, J. (2014). Indian stock market influenced by the global stock market: A study of select world major stock markets. Samzodhana - Journal of Management Research, 2(1), 12-24.

31. Mohanasundaram, T., \& Karthikeyan, P. (2015). Cointegration and stock market interdependence: Evidence from South Africa, India, and the USA. SAJEMS, 18(4), 475-485. https://doi. org/10.4102/sajems.v18i4.1029

32. Nadia, L. N., \& Mora, B. R. (2018). A Comparative Analysis of Mutual Fund Schemes. International Journal of Engineering Technology Science and Research, 5(3), 712-717. Retrieved from http://ijetsr.com/images/short_pdf/1521516691_712 717-ieteh265_ijetsr.pdf

33. Pandow, B. A., \& Butt, K. A (2017). Risk and Return Analysis of Mutual Fund Industry in India. International Journal of Banking and Financial Dynamics, 1(1), 5465. https://doi.org/10.20448/journal.525.2017.11.54.65

34. Paramati, S. R., Gupta, R., \& Roca, E. (2012). International Equity Markets Integration: Evidence from Global Financial Crisis and Structural Breaks. Retrieved from https://www.semanticscholar.org/ paper/International-Equity-Markets-Integration-\%3A-EvidenceParamati-Gupta/e54017fb3e8846d8 ef46ce100b502021bc14c206?p2df

35. Perron, P. (1990). Testing for a Unit Root in a Time Series with a Changing Mean. Journal of Business and Economic Statistics, 8(2), 153-162. https://doi. org/10.2307/1391977

36. Pokhriyal, A., Singh, L., \& Singh, S. (2011). Comparative analysis of the impact of various global stock markets and determinants on Indian stock market performance - A case study using multiple linear regression and neural networks. In S. Dua, S. Sahni, D.P. Goyal (Eds.), Information Intelligence, Systems, Technology and Management, 141 (pp. 277-286). https://doi. org/10.1007/978-3-642-19423-8_29

37. Raju, J. K., Manjunath, B. R., \& Rehaman, M. (2018). An Empirical study on the effect of Gross Domestic Product on Inflation: Evidence Indian Data. Academy of Accounting and Financial Studies Journal, 22(6), 1-11. Retrieved from https://www.abacademies.org/ articles/an-empirical-study-on-theeffect-of-gross-domestic-producton-inflation-evidence-indiandata-7777.html

38. Rani, G., \& Hooda, V. S. (2017). Performance Evaluation of Mutual Fund Schemes: A Study of Selected Topper Schemes. IOSR Journal of Business and Management (IOSR$J B M), 19(10), 1-6$. Retrieved from https://pdfs.semanticscholar.org/ed 0e/4f8422ff29e8abf8fb0f63a6a3806 df81faf.pdf

39. Rao, K. V., \& Daita, N. (2011). Fundamental Factors influencing Investment in Mutual Funds-EIC Approach-A Case Study of RCAML. The Indian Journal of Commerce,
64(3), 61-73. Retrieved from https:// www.semanticscholar.org/paper/ Fundamental-Factors-InfluencingInvestments-in-\%E2\%80\%93-A-Ra o-Daita/623alb336866164d1a0cc97 229345f8e53b5ee3c

40. Reuters. (2017). India eases foreign investment rules for corporate debt. Retrieved from https://www.reuters. com/article/us-india-cenbankdebt/india-eases-foreign-investment-rules-for-corporate-debtidUSKCN1BX20M?il=0

41. Samadder, S., \& Bhunia, A. (2018). Integration between Indian Stock Market and Developed Stock Markets. Journal of Commerce and Accounting Research, 7(1). Retrieved from http://www.publishingindia. $\mathrm{com} / \mathrm{jcar} / 47 /$ integration-betweenindian-stock-market-and-developed-stock-markets/671/4701/

42. Sharma, N. K. S., \& Ravikumar, R. (2013). Analysis of The Risk and Return Relationship of Equity Based Mutual Fund in India. International Journal of Advancements in Research \& Technology, 2(8), 289-295. Retrieved from http://www.ijoart.org/docs/ ANALYSIS-OF-THE-RISK-ANDRETURN-RELATIONSHIP-OFEQUITY-BASED-MUTUALFUND-IN-INDIA.pdf

43. Taneja, Y. P. (2012). Stock market integration: A study of the world's major stock exchanges with special reference to India. Vision, 16(2), 109-120. https://doi. org/10.1177/097226291201600204

44. Watson, J., \& Wickramanayake, J. (2012). The relationship between aggregate managed fund flows and share market returns in Australia. Journal of International Financial Markets, Institutions, and Money, 22(3), 451-472. https://doi. org/10.1016/j.intfin.2012.02.001

45. White, H. (1980). A heteroskedasticity-consistent covariance matrix estimator and a direct test for heteroskedasticity. Econometric, 48(4), 817-838. https:// doi.org/10.2307/1912934 